\title{
Letter to the editor regarding the article by Yazici et al.
}

\author{
Mehmet Fatih Sönmez
}

Received: 15 March 2013/Accepted: 26 March 2013/Published online: 2 April 2013

(C) Springer-Verlag Berlin Heidelberg 2013

We read with great enthusiasm the recent study of de Yazici et al. [1] entitled "Reduction of cisplatin ototoxicity in rats by oral administration of pomegranate extract". Yazici et al. demonstrated that oral administration of pomegranate extract $(\mathrm{PE})$ had a significant protective effect on external ciliated cells, stria vascularis, and spiral ganglion cells, which are damaged by cisplatin.

I should mention to you that, in this study, Fig. 3 belongs to organ of corti and Fig. 4 present findings of stria vascularis. However, unfortunately somehow, it appears that there has been confusion in the figure titles. In other words; figure titles has written wrong, figure title 3 has written with Fig. 4 and figure title 4 has written with Fig. 3. If you could please make the corrections and change the figure title places 3 and 4, we would be deeply appreciated.

\section{Reference}

1. Yazici ZM, Meric A, Midi A, Arınc YV, Kahya V, Hafız G (2012) Reduction of cisplatin ototoxicity in rats by oral administration of pomegranate extract. Eur Arch Otorhinolaryngol 269(1):45-52

M. F. Sönmez $(\square)$

Department of Histology and Embryology, Faculty of Medicine, Erciyes University, 38039 Kayseri, Turkey

e-mail: drmfatihsonmez@hotmail.com 